(2)

OPEN ACCESS

\title{
Multiple melanoma in a burns scar
}

\author{
Phillip Cantwell, ${ }^{1}$ Adrian Brooks ${ }^{2}$
}

${ }^{1}$ Plastic Surgery, Royal Perth Hospital, Perth, Western Australia, Australia ${ }^{2}$ Department of Plastic Surgery, Joondalup Health Campus, Joondalup, Australia

\section{Correspondence to} Dr Phillip Cantwell, pcc998@uowmail.edu.au

Accepted 3 December 2018

\section{SUMMARY}

It is well known that up to $2 \%$ of chronic burn scar lesions can transform into malignant tumours, however, melanoma formation at these sites is extremely rare. This case report describes a burns case, which progressed to four melanomas in a 78-year-old male patient's little finger, 40 years after the initial incident. The patient underwent $3 \mathrm{~mm}$ punch biopsies, then digital amputation of the finger with pathology-proven melanoma. Histopathology investigation demonstrated three melanoma in situ and one invasive melanoma with a Breslow thickness of $1 \mathrm{~mm}$. These findings are rare with few reports of melanoma in burn scars in the literature. This case report highlights the vigilance required from clinicians when performing skin examinations, and the importance of biopsies to newly pigmented lesions.

\section{BACKGROUND}

An accepted phenomenon is the transformation of chronic burn scars into aggressive cutaneous malignancies, known as Marjolin ulcers. ${ }^{1}$ These malignancies represent $2 \%$ of squamous cell carcinoma (SCC) and less commonly, basal cell carcinoma (BCC). ${ }^{1}$ Few cases of melanoma arising in burn scars are reported in the literature, with only four previous cases of multiple melanoma in burns scars reported to date. ${ }^{2}$ The case described is significant as it involves melanoma formation at four sites within a previously stable burns scar.

\section{CASE PRESENTATION}

A 78-year-old male patient presented with four dark pigmented lesions on his left little finger, at the site of a molten polyethylene rope yachting

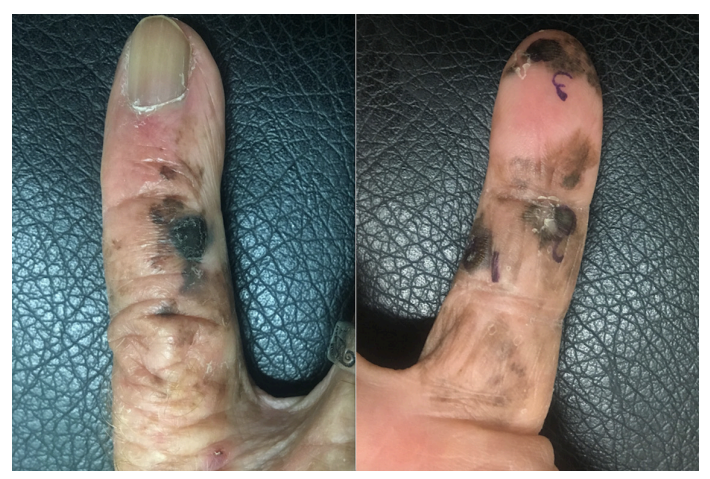

Figure 1 Photographs of the patient's left little finger. The image to the left demonstrates a dorsal view while the image to the right demonstrates a volar view.

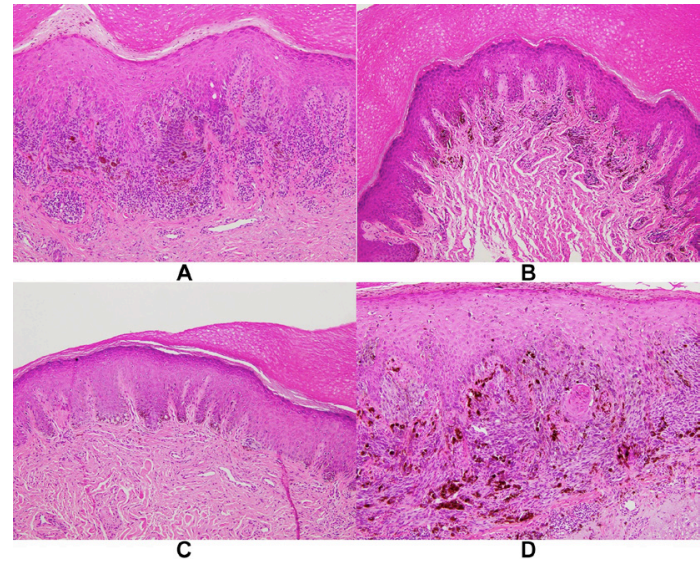

Figure 2 H\&E-stained sections demonstrating: (A) melanoma in situ with regression; (B) melanoma in situ; (C) melanoma in situ; (D) invasive melanoma with Breslow thickness $1 \mathrm{~mm}$.

accident 40 years previous. The burn was managed conservatively without medical intervention, and materialised into a stable pigmented scar. Two years prior to presentation, four separate dark pigmented lesions developed within the scar site. The patient had sought medical advice on their appearance after prompting during a routine skin cancer check. After detection of the lesions by the patient's general practitioner, the patient was referred to a specialist surgeon for assessment.

The patient had a background of ischaemic heart disease and had a nasal bridge BCC excised 2 years earlier, but no other skin cancer history. He had an 81 pack-year history but ceased smoking 15 years ago, was a retired labourer and had type 3

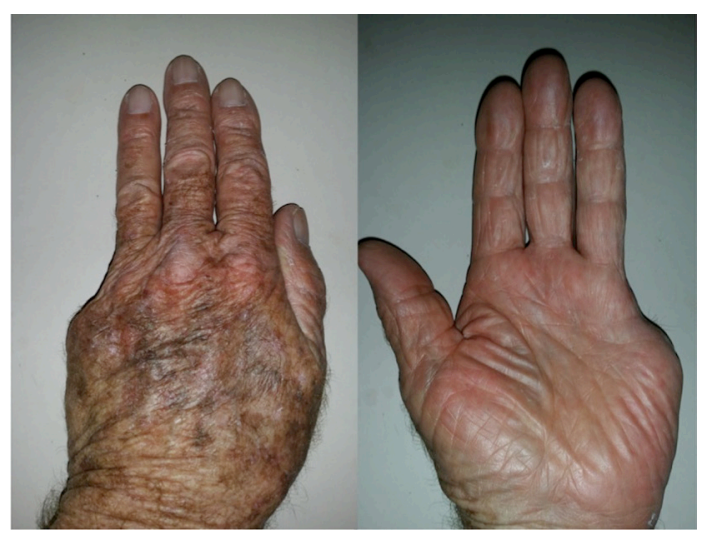

Figure 3 Photographs of the patient's hand 9 months after the operation. The image to the left demonstrates a dorsal view while the image to the right demonstrates a volar view. 
Fitzpatrick phototype skin. Figure 1 shows photographs of the lesions at initial presentation.

\section{INVESTIGATIONS}

Punch biopsies of the four lesions confirmed three melanoma in situ and one invasive melanoma, with a Breslow thickness of $1 \mathrm{~mm}$. The invasive melanoma showed lentiginous and nested patterns with prominent pagetoid spread of atypical melanocytes with regression present.

\section{TREATMENT}

The patient underwent a digital amputation and a sentinel lymph node biopsy (SLNB). Histopathology from the amputation demonstrated four distinct melanomas, with no nodal metastasis identified on SLNB. The patient did not receive any adjunct therapy. Figure 2 demonstrates microphotographs of the histological analysis.

\section{OUTCOME AND FOLLOW-UP}

The patient has recovered well since surgery. It is 9 months since diagnosis and there have been no signs of recurrence. The patient is being followed up every 3 months for local and regional lymph node examination. Figure 3 shows the patient's hand at 9 months follow-up.

\section{DISCUSSION}

An accepted phenomenon is the transformation of chronic burn scars into aggressive cutaneous malignancies, known as Marjolin ulcers. $^{1}$ These malignancies represent $2 \%$ of SCCs and less commonly, BCCs. ${ }^{1}$ Few cases of melanoma arising in burn scars are reported in the literature, ${ }^{2}$ with a 2005 review by Atzeni et $a l^{3}$ finding 36 reported cases, 4 of which involved multiple melanoma transformations in a single burns scar. Only one additional case report has been published since then. ${ }^{4}$

Our patient had no other melanomas surrounding the burn or at any other sites. A single melanoma within a scar or melanoma outside of the scar site may have simply been an incidental finding and of no particular relation to the burns injury. However, in the context of four separate melanomas forming within a previously stable scar without pre-existing naevi, it is indicated that the malignant transformation was related to the burns injury.

The mechanism for melanoma formation in a burn scar is not fully known. Burns as a causative agent for malignant transformation could be compared with known melanoma risk factors, which indicate that severe sunburns of a single area produce greater risk than chronic sun damage. ${ }^{5}$ Several studies have suggested a disease mechanism secondary to carcinogenic toxins produced at the site of the burn, ${ }^{6}$ while others have postulated that burns increase the susceptibility to neoplastic change once a carcinogen is present. ${ }^{7}$

The long latency period of 40 years in our patient was not atypical with previous papers reporting latency periods of up to 70 years. ${ }^{4}$ This patient had local melanoma, as SLNB identified no nodal metastasis. In previous case reports, metastases were commonly present at the time of diagnosis. This was considered to be secondary to the late diagnosis following a slow formation from a once stable scar. ${ }^{8}$

\section{Patient's perspective}

The burn occurred when I was at the yacht club alone on board the yacht, working in the cockpit and I simply leaned overboard to dunk my hand in the saline water. The act of heating the (polyethylene) rope ends in this case was by use of a gas filled disposable cigarette lighter.

I didn't seek any treatment from a Doctor or Hospital. I think I may have been in a state of shock following the hand dunking, and probably had a cigarette to calm myself before cleaning up the cockpit. I do recall there was significant pain but cannot recall for how long any discomfort continued. I do not recall ever bandaging or covering the hand.

Ultimately the actual burn markings seemed to cycle through stages of being very intensely 'black' and highly visible presenting as being right on top of the outer skin layer, then gradually fading over time (maybe couple of months?) to less intense black and presenting as being under the top layer of skin.

\section{Learning points}

- The indication for biopsy in stable scars that demonstrate newly pigmented areas.

- The prospect of cutaneous malignant transformation of stable burns scars.

The importance of a thorough skin examination.

Contributors $P C$ took leadership in performing research and writing of this manuscript. $A B$ was the consultant for this patient and was involved in obtaining collection of results and drafting of the manuscript.

Funding The authors have not declared a specific grant for this research from any funding agency in the public, commercial or not-for-profit sectors.

Competing interests None declared.

Patient consent for publication Obtained.

Provenance and peer review Not commissioned; externally peer reviewed.

Open access This is an open access article distributed in accordance with the Creative Commons Attribution Non Commercial (CC BY-NC 4.0) license, which permits others to distribute, remix, adapt, build upon this work non-commercially, and license their derivative works on different terms, provided the original work is properly cited and the use is non-commercial. See: http://creativecommons.org/ licenses/by-nc/4.0/

\section{REFERENCES}

1 Fleming MD, Hunt JL, Purdue GF, et al. Marjolin's ulcer : a review and reevaluation of a difficult problem. J Burn Care Rehabil 1990;11:460-9.

2 Bero SM, Busam KJ, Brady MS. Cutaneous melanoma arising in a burn scar: two recent cases and a review of the literature. Melanoma Res 2006;16:71-6.

3 Atzeni M, Serratore F, Zaccheddu F, et al. Multiple melanoma arising on a burn scar and extensive sunburn: a case report and a review of the literature. Melanoma Res 2009;19:195-8.

4 Uchida S, Oiso N, Shiga K, et al. Malignant melanoma on a thermal burn scar with an interval of more than 70 years. Case Rep Dermatol 2016;8:207-9.

5 Gandini S, Sera F, Cattaruzza MS, et al. Meta-analysis of risk factors for cutaneous melanoma: II. Sun exposure. Eur J Cancer 2005;41:45-60.

6 Ozek C, Cankayali R, Bilkay U, et al. Marjolin's ulcers arising in burn scars. J Burn Care Rehabil 2001:22:384-9.

7 Giblin T, Pickrell K, Pitts W, et al. Malignant degeneration in burn scars. Ann Surg 1965:162:291-7.

8 Kikuchi H, Nishida T, Kurokawa M, et al. Three cases of malignant melanoma arising on burn scars. J Dermato/ 2003;30:617-24. 
Copyright 2018 BMJ Publishing Group. All rights reserved. For permission to reuse any of this content visit https://www.bmj.com/company/products-services/rights-and-licensing/permissions/

BMJ Case Report Fellows may re-use this article for personal use and teaching without any further permission.

Become a Fellow of BMJ Case Reports today and you can:

- Submit as many cases as you like

- Enjoy fast sympathetic peer review and rapid publication of accepted articles

- Access all the published articles

- Re-use any of the published material for personal use and teaching without further permission

For information on Institutional Fellowships contact consortiasales@bmjgroup.com

Visit casereports.bmj.com for more articles like this and to become a Fellow 